\title{
A Response to "Depression and Anxiety Among Medical Students: A Brief Overview.” - The Issue of Stigmatisation in the Medical Profession [Response to the Letter]
}

\begin{abstract}
Ahmad A Mirza (D'
Mukhtiar Baig $\mathbb{D}^{2}$

Ghada M Beyari ${ }^{3}$

Mohammed Aiman Halawani ${ }^{3}$

Abdulrahim A Mirza ${ }^{4}$

'Department of Otolaryngology, Head and Neck Surgery, Faculty of Medicine in Rabigh, King Abdulaziz University, Jeddah, Saudi Arabia; ${ }^{2}$ Department of Clinical Biochemistry/Medical Education, Faculty of Medicine in Rabigh, King Abdulaziz University, Jeddah, Saudi Arabia; ${ }^{3}$ Faculty of Medicine, Umm Al-Qura University, Makkah, Saudi Arabia; ${ }^{4}$ Department of Surgery - Division of Urology, Ministry of National Guard - Health Affairs, Jeddah, Saudi Arabia
\end{abstract}

\section{Dear editor}

Thank you for the opportunity to respond to the letter by Anushka Sharma ${ }^{1}$ comments. It is apparent that we did not discuss the barriers in place that facilitate increases in rates of mental ill-health amongst healthcare professionals in our brief review. However, we pointed out to some factors that potentially increase the risk of depression and anxiety among medical students. We appreciate the author's point of view that stigmatization of mental illness is a widespread societal issue which affects the medical profession and its workers. In our overview, we took account of the importance of mental illness and its associated risk facotors, and we emphasized how important it is to synthesize a higher level of evidance in this undeniable topic.

\section{Disclosure}

The authors report no conflicts of interest in this communication.

\section{Reference}

1. Sharma AA. Response to "depression and anxiety among medical students: a brief overview." - the issue of stigmatisation in the medical profession [letter]. Adv Med Educ Pract. 2021;12.
Correspondence: Ahmad A Mirza

Department of Otolaryngology, Head and Neck Surgery, Faculty of Medicine in Rabigh, King Abdulaziz University, P.O. Box 80200, Jeddah 21589, Saudi Arabia

Email aamirzal@kau.edu.sa 
Dove Medical Press encourages responsible, free and frank academic debate. The content of the Advances in Medical Education and Practice 'letters to the editor' section does not necessarily represent the views of Dove Medical Press, its officers, agents, employees, related entities or the Advances in Medical Education and Practice editors. While all reasonable steps have been taken to confirm the content of each letter, Dove Medical Press accepts no liability in respect of the content of any letter, nor is it responsible for the content and accuracy of any letter to the editor.

Advances in Medical Education and Practice

Dovepress

\section{Publish your work in this journal}

Advances in Medical Education and Practice is an international, peerreviewed, open access journal that aims to present and publish research on Medical Education covering medical, dental, nursing and allied health care professional education. The journal covers undergraduate education, postgraduate training and continuing medical education including emerging trends and innovative models linking education, research, and health care services. The manuscript management system is completely online and includes a very quick and fair peer-review system. Visit http://www.dovepress.com/testimonials.php to read real quotes from published authors. 